\title{
Archive Files on the Şahin Geray's Contribution to the Russo-Persian Relations
}

\author{
V.A.Shorokhov, T. A. Slesarev
}

For citation: Shorokhov V.A., Slesarev T. A. Archive Files on the Şahin Geray's Contribution to the Russo-Persian Relations. Vestnik of Saint Petersburg University. History, 2020, vol. 65, issue 2, pp. 618632. https://doi.org/10.21638/11701/spbu02.2020.217

The paper aims to provide insight into the content of the diplomatic documents from the "Persian" fund of the Russian State Archive of Ancient Acts, which reveals the role of the Crimean prince Şahin Geray in relations between Safavid Iran and the Russian Tsardom at the turn of the 1620 s and 1630s. A detailed source examination is given to a group of nineteen texts dated by 1630. This set consists of letters in Turki and Farsi as well as their Russian translations and a preface by the administrators of Astrakhan. The addressees of correspondence were Astrakhan and Terek voivodes and the governor of the non-Russian population of the Terky Sholokh Cherkassky. The senders were Shah Safi I, Şahin Geray, beglerbeg of Shirvan Qazaq Khan and shamkhal of Tarki Ildar. The materials analyzed reflect the attempts of the aforementioned political emigrant, with the support of the Shahs Abbas the Great and then Safi I, to obtain diplomatic and military assistance from Moscow and the local Russian authorities of the Ciscaucasia in reconquering the Crimea. The authors reveal the details of the plan of Şahin Geray and the reasons for the Russian negative stance on any combinations involving the former Crimean qalga. The scholars conclude that Shah's supportof the political figure unacceptable for the Romanov monarchy became one of the significant factors holding back the development of Russian-Persian relations in the period under review. In the appendix, there is a Turki text of the firman by Safi I to voivodes, as well as its contemporary and recent translations into Russian.

Keywords: Russo-Persian Relations in $17^{\text {th }}$ century, Şahin Geray, Safi I, Mikhail Fyodorovich, archive files.

Vladimir A. Shorokhov - PhD in History, Associate Professor, St. Petersburg State University, 7-9, Universitetskaya nab., St. Petersburg, 199034, Russian Federation; v.shorohov@spbu.ru

Владимир Андреевич Шорохов - канд. ист. наук, доц., Санкт-Петербургский государственный университет, Российская Федерация, 199034, Санкт-Петербург, Университетская наб., 7-9; v.shorohov@spbu.ru

Timur A. Slesarev - Visiting Researcher, St. Petersburg State University, 7-9, Universitetskaya nab., St. Petersburg, 199034, Russian Federation; t.slesarev@spbu.ru

Тимур Анисович Слесарев - приглашенный исследователь, Санкт-Петербургский государственный университет, Российская Федерация, 199034, Санкт-Петербург, Университетская наб., 7-9; t.slesarev@spbu.ru

Исследование выполнено за счет средств проекта РНФ № 18-78-10052 «Документальная история русского направления дипломатии Сефевидов (1501-1722 гг.)».

The study was supported by the research grant No. 18-78-10052 "The Documentary History of the Russian Strand of Safavid Diplomacy (1501-1722)” of the Russian Science Foundation.

(C) Санкт-Петербургский государственный университет, 2020 


\section{Архивные документы о роли крымского царевича Шагин Гирея в русско-персидских отношениях}

\section{В. А. Шорохов, Т. А. Слесарев}

Для цитирования: Shorokhov V.A., Slesarev T. A. Archive Files on the Şahin Geray’s Contribution to the Russo-Persian Relations // Вестник Санкт-Петербургского университета. История. 2020. Т.65. Вып. 2. С. 618-632. https://doi.org/10.21638/11701/spbu02.2020.217

Исследование посвящено характеристике и анализу содержания дипломатических документов из «персидского» фонда Российского государственного архива древних актов, раскрывающих роль крымского царевича Шагин Гирея в отношениях между Сефевидским Ираном и Русским царством на рубеже 1620-1630-х гг. Подробное источниковедческое описание дается группе из 19 текстов, датированных 1630 г. и представляющих собой официальные послания на тюрки и фарси, а также их русские переводы и предваряющую отписку воевод Астрахани Федора Куракина и Ивана Коробьина. Адресатами корреспонденции выступают астраханские, терские администраторы и глава нерусского населения Терского города Шолох Черкасский. Отправители: шах Сефи I, Шагин Гирей, ширванский беглербег Казак-хан и тарковский шамхал Ильдар. Изученные материалы отражают отчаянные попытки одиозного политического эмигранта при поддержке персидских шахов Аббаса Великого, а затем Сефи I добиться всесторонней помощи от Москвы и местных русских властей Предкавказья в деле отвоевания Крымского юрта. Авторами установлены детали планировавшейся Шагин Гиреем военной авантюры: сроки похода, декларация участия в нем персидских региональных контингентов, параметры запрашиваемой российской помощи войсками и обеспечением коммуникаций. Раскрыты и причины негативного отношения Русского царства к любым комбинациям с участием бывшего крымского калги. Это и его попытки переманить в сферу влияния Бахчисарая всех ногайцев, и связи с враждебной Москве Казыевой Кабардой, и крайне агрессивная антирусская политика в период пребывания во второй по значимости должности Крымского ханства. Поддержка столь неприемлемой для монархии Романовых политической фигуры, по мнению исследователей, стала одним из значимых факторов, сдерживавших развитие русско-персидских отношений в рассматриваемый период. В приложении к статье публикуются тюркский арабографический текст фирмана шаха Сефи терским воеводам, а также его переводы на русский (1630 г.) и современный английский языки.

Ключевые слова: русско-персидские отношения XVII века, Шагин Гирей, Михаил Федорович, Сефи I, архивные документы.

Russian-Persian relations between 1620s and 1660s remain, as yet, underresearched. This is especially true for major decisions in politics and diplomacy, which have received very little attention ${ }^{1}$ research-wise as compared to bilateral trade and economic relations and conflicts which were uncommon. The fact stands in contrast to the significance that

${ }^{1}$ Novosel'tsev A.P. Russko-iranskie otnoshenia v pervoi polovine XVII v. // Mezhdunarodnye sviazi Rossii v XVII-XVIII vv. (ekonomika, politika i kul'tura). Moscow, 1966. P. 103-121; Filatova T. "A k shakhu v ego plat'e ne khoditi": Rossiiskie diplomaty pri dvore Abbasa Velikogo // Rodina. 2009. No. 12. P. 158-161; Bazilenko I. V. Ocherki istorii rossiisko-iranskikh otnoshenii (kon. XVI v. - nach. XX v.). St. Petersburg, 2017. P.22-31; Shorokhov V., Yastrebova O., Rezvan M., Pischurnikova E., Andreev A. Shāh Safī I Safawid's "missing manuscript" addressed to Mikhail Fyodorovich Romanov // Manuscripta Orientalia. December 2018. Vol.24, no. 2. P. 62-67. 
the period had in terms of strengthening of numerous connections between Tsardom of Russia and Qizilbash Empire. Isfahan, while retaining the status of important international actor under Abbas the Great's successors, Safi I (1629-1642) and Abbas II (1642-1666), sought an alternative to the Ottoman route for transit to Europe ${ }^{2}$. That is why Iran was among the few counterparties of Moscow which were, under certain conditions, ready to advance their relationship to what we could call, in contemporary terms, "a strategic partnership". The Romanovs also expressed their intention to cooperate with their southern neighbor and make some tactic concessions in order to maintain good rapport ${ }^{3}$ with them. Despite that, since the death of Abbas the Great in January 1629, both the amount and quality of the two parties' interaction in the sphere of politics were slowly degrading, which led to Russia and Persia coming to the verge of an armed conflict by the beginning of 1650 s.

So what was it that led to the "cold peace"?

Some disagreement between the Russian Tsardom and the Safavid Empire can partly be attributed to geography. The key difference lay in the disputes over spheres of influence on the eastern side of the North Caucasus and in the Caspian region, which progressively led to a conflict of 1650-1653 and military campaign of the Cossacks in 1668-16694.

Another set of problems comprised some issues of both religious and political nature, which manifested themselves, inter alia, in Moscow's seeking to protect Kartli, Kakhetia and (later) Imereti, which were "of Common Faith". However, the protection was largely declarative given both the long distance between Western Transcaucasia and Russia and Iran's readiness to "nominally" but generously compensate the partner for their concern. The most famous of such events is the transfer by Abbas of the Holy Robe of Jesus captured in Mtskheta ${ }^{5}$ to Mikhail Fyodorovich (I) in 1625. Nevertheless, as the Tsardom grew stronger and the influence of Teimuraz I of Kakheti in 1630s gained momentum, the tension in Russian-Persian relations could not but intensify ${ }^{6}$.

Another potential irritant in the bilateral relations was the very trade that stimulated them. The status of state trade agents, prospects of transit and of opening caravansary in various regions of the neighboring country, monopoly on raw silk and hunt-

2 The Cambridge History of Iran. Vol. 6: The Timurid and Safavid Periods. Cambridge, 1986. P. $278-$ 304, 397-400.

${ }^{3}$ Novosel'tsev A.P. Russko-iranskie otnoshenia... P.113-121; Koraev T.K. Moskovskaia Rus' i Safavidskii Iran v Prikaspii XVI-XVII vv.: sosedstvo, sopernichestvo, sosushhestvovanie // Istoricheskii vestnik. 2015. Vol. XI (158): Rossiia i islamskii mir. P. 185-192.

${ }^{4}$ Kusheva E.N. Materialy nauchnoi sessii po istorii narodov Dagestana: Russko-dagestanskie otnoshenia v XVI-XVII vekakh. Makhachkala, 1954. P. 19-25; Kusheva E. N. Narody Severnogo Kavkaza i ikh sviazi s Rossiei (vtoraia polovina XVI - 30-e gody XVIII veka). Moscow, 1963. P. 304-323; Murtazaev A. O. Kaitag v VIII - pervoi polovine XIX v. (issledovanie politicheskoi istorii i roli v sisteme politicheskikh struktur Severo-Vostochnogo Kavkaza). Makhachkala, 2015. P.224-268; Zevakin E.S. Azerbaidzhan v nachale XVIII veka. Baku, 1929; Babulin I. B. Russko-iranskii voennyi konflikt 1651-1653 gg. // Reitar. 2006. No. 31 (7). P. 6-33; Koraev T. K. Moskovskaia Rus' i Safavidskii Iran... P. 182-192.

${ }_{5}$ On the matter, see: Belokurov S. A. Delo o prisylke shakhom Abbasom rizy gospodnei tsariu Mikhailu Fedorovichu v 1625 godu. Moscow, 1891.

${ }^{6}$ Meskhia Sh. A., Tsintsadze Ia. Z. Iz istorii russko-gruzinskikh vzaimootnoshenii. Tbilisi, 1958. P. 6874; Bushev P. P. Posol'stvo V. G. Korob’ina i A. Kuvshinova v Iran 1621-1624 gg. // Iran. Ekonomika. Istoriia. Istoriografiia. Literatura / ed. by N. A. Kuznetsova. Moscow, 1976. P. 121-133; Bazilenko I. V. Ocherki istorii rossiisko-iranskikh otnoshenii... P. 26-30; Koraev T. K. Moskovskaia Rus' i Safavidskii Iran... P. 178-180. 
ing birds, as well as some other issues were taken care of as late as the end of reign of Abbas II ${ }^{7}$.

However, the abovementioned problems never lost their significance during the whole period from annexation of Astrakhan to Persian military campaigns launched by Peter the Great, and therefore simply stating the facts will not suffice to explain the deterioration of the relations, which was certainly gradual, that took place in the second quarter of the $17^{\text {th }}$ century. In our view, the main stumbling block in the endeavors to create military and political union of the Romanovs and the Safavids was the issue of the Ottoman Crimea. Şahin Geray ( 1585-1641) was one of the most famous gentlemen of fortune who embodied irreconcilable differences between the Romanovs and the Safavids in the 1610-1630s. This member of the ruling dynasty of the Crimean khanate who occupied senior public positions of nureddin (1609-1610) and qalga (1610, 1624-1628) was, during the period of 1614-1632, the power that Persia supported in the conflict with the Ottoman Empire. That being said, he was also the most consistent advocate of the union of the Crimean elite with the Polish-Lithuanian Commonwealth against the Tsardom of Russia and the Porte. Additional factors that worried Moscow were tsarevich's connections ${ }^{8}$ in the Lesser Nogai Horde, which constantly threatened "tsar's borderlands", as well as his networks in the North Caucasus ${ }^{9}$.

Şahin Geray's name occurred rather often on the pages of works on history of Russian-Crimean, Russian-Persian and Russian-Caucasian relations of the first third of the $17^{\text {th }}$ century ${ }^{10}$. Some diplomatic documents throwing light on a number of dramatic relations between him and the Russian Tsardom were also published ${ }^{11}$. In our opinion, the topic nevertheless cannot be deemed well-researched. First of all, in all the known cases when it was addressed, it took the form of, more or less, extended digressions. As a matter of fact, previous works on the subject seem to place our character, often artificially, into one of various contexts, none of which is indicative of his endeavors. Secondly, it is the period of his Crimean presence that remains the most studied, while the full frame of his actions during his first and second immigrations to Iran has not yet been reconstructed.

\footnotetext{
7 On the Russian-Persian trade during the period see: Khozhenie kuptsa Fiodora Kotova v Persiiu. Moscow, 1958; Kostikov S. E., Yastrebova O. M. Chelobitnye iranskogo kupchiny Khvadzhi Rakhmata tsariu Mikhailu Fedorovichu (1613-1645) iz Rossiiskogo gosudarstvennogo arkhiva drevnikh aktov // Pis'mennye pamiatniki Vostoka. 2019. Vol. 16, no. 2 (37). P. 122-145; Kukanova N. G. Ocherki po istorii russko-iranskikh torgovykh otnoshenii v XVII - pervoi polovine XIX veka: (Po materialam rus. arkhivov). Saransk, 1977; Dzarasov A. A., Riabtsev A. L. Usloviia morskoi torgovli Rossii na Kaspii v XVII veke // Vestnik of Khetagurov North Ossetian State University. Social Sciences. 2013. No.1. P.20-24; Koraev T. K. Moskovskaia Rus' i Safavidskii Iran... P. 183-184, 188-190.

${ }^{8}$ It is exactly that way Şahin Geray's title as indicated in his personal seal is translated in Ambassadorial prikaz. See, for instance: Otpiski astrakhanskikh voevod o persidskikh delakh // RSAAA. F. 77. Op. 1. 1630. D.2. L. 16.

${ }^{9}$ Kusheva E. N. Materialy nauchnoi sessii po istorii narodov Dagestana... P.22-23; Trepavlov V. V. Malaia Nogaiskaia Orda. Ocherk istorii // Tiurkologicheskii sbornik. 2003-2004: Tiurkskie narody v drevnosti i srednevekov'e / ed. by S. G. Kliashtornyi. Moscow, 2005. P.296-303; Dzamikhov K. F. "V sluzhbe i oborone...": Kabarda i Rossiiskoe gosudarstvo: epokha voenno-politicheskogo sotrudnichestva (1550 nachalo 1770-kh godov). Nalchik, 2017. P. 96.

10 Novoselskii A.A. Bor'ba Moskovskogo gosudarstva s tatarami v pervoi polovine XVII veka. Moscow; St. Petersburg, 1948. P. 107-134; Kusheva E. N. Narody Severnogo Kavkaza... P. 309-310, 312-315; Novosel'tsev A. P. Russko-iranskie otnoshenia... P. 117-119.

${ }^{11}$ Russko-dagestanskie otnoshenia XVII - pervoi chetverti XVIII v. Makhachkala, 1958. P.94-95, 99-101, 104-117, 124-129.
} 
Therewith, the range of sources leaves room for several advanced researches. And finally, scholars have mostly followed the relations between Şahin Geray and Moscow predominantly on the basis of "Turkish", "Crimean", "Kabardian", "Kumik" affairs of the Russian State Archive of Ancient Acts (hereinafter RSAAA). Documents from the archival fund 77 ("Dealings between Russia and Persia") have been used only occasionally ${ }^{12}$, while it is these documents that may allow to make a detailed research of the direct contacts between the Crimean exile with his Russian counterparties that took place between the 1620s and 1630s. We believe that researching the contacts made by Şahin Geray will bring the question of the process of Russian-Persian relations after the death of Abbas the Great and the reasons for their alienation to a new level.

The objective of this research is to characterize and analyze the content of diplomatic documents from the Persian archival fund of RSAAA that uncover the role of the future Crimean qalga Şahin Geray in the relations between the Safavid's Iran and the Romanovs' monarchy in 1629-1632.

In order to lay the groundwork for understanding of the situation described in the documents introduced here, it is necessary to briefly outline the events that predefined the complete rejection of the tsarevich's figure by Moscow.

Soon after Şahin Geray's appearance in Iran in 1614, he gained confidence of Abbas the Great, who consequently sent him to the Caucasus to organize a coalition between the Lesser Nogai Horde and Kabardian and Dagestani rulers against the Crimean khan Janibek ${ }^{13}$. Taking into account the disputed status of many a Caucasian region, Ambassadorial Prikaz observed, in dismay, the appearance of the emissary the highborn shah in Derbent in the summer of $1616^{14}$. No optimism was added by announcements made by Abbas's trade representative Magamet-Khasym in the autumn of the same year that the tsarevich was sent "to Shchelkaly" 15 accompanied by an army of 50 thousand, potentially moving on to Sunzha - ostensibly, to prevent an attack coming from Crimea ${ }^{16}$. However, in the face of devastation, need for a loan from Persia and intrinsic importance of distraction of the Tatars from the "tsar's borderlands", the Russian authorities did not curb the activities of Şahin Geray.

By 1619 , the situation had changed. The documents analyzed by V.V. Trepavlov bear witness that the tsarevich, having raised the Lesser Nogai Horde to a war with Bakhchisarai, fled "to Kumiks" as soon as khan's army appeared, having abandoned his allies ${ }^{17}$. Tactically, this proved to be beneficial for Moscow since the beaten nomads took to flight to the vicinity of Astrakhan, bowed low asking for citizenship and, for a time, ceased to be dangerous. On the other hand, the arrival of Şahin Geray in the traditional area of Russia's influence only boded for new ventures and disagreements with both the khan and the sultan, and the problems were not long in coming.

12 Novosel'tsev A.P. Russko-iranskie otnoshenia... P. 310, 313.

13 Kusheva E. N. Narody Severnogo Kavkaza... P. 312; Novosel'tsev A. P. Russko-iranskie otnoshenia... P. 118.

${ }_{14}$ Bushev P.P. Istoriia posol'stv... p. 137.

15 It is possible that it meant to the domain of Shamkhal of Tarki - a subject to both shah and tsar (see: Kusheva E. N. Narody Severnogo Kavkaza... P. 307-308).

16 Pamiatniki diplomaticheskikh i torgovykh snoshenii Moskovskoy Rusi s Persiei / ed. by N. I. Veselovskii. Vol. 3. St. Petersburg, 1898. P.262, 273-274.

17 Trepavlov V. V. Malaia Nogaiskaia Orda... P. 296-298. 
Already in the spring of 1620, the shah's emissaries and Şahin Geray's people entered into direct negotiations with murzas of the Greater Nogai Horde regarding the formation of an alliance. At first voivods and Ambassadorial Prikaz tried to "keep out of quarrel with both ${ }^{18}$ ", however, as the second half of the year approached, their patience started to dry out. The reason behind this was the information received that Şahin Geray, thorough Abbas the Great's falconer, Bharkhadar-aga, urged the Nogai murzas (Ishterek-muzra Tenekhmatov, Aksakel' Mamet'-murza Tinbayev and others) to turn from "the tsar's majesty and to the Crimean" side, effectively undermining Russian-Persian relations and helping the Crimean khan, a "foe" of both tsar and shah ${ }^{19}$. Judging by the fact that shah's ambassador Bulat-bek covered up for the tsarevich in Moscow in March $1621^{20}$, it is safe to assume that the Nogai played their card with Abbas in the know. It is probable that the shah attempted to help Şahin Geray by the instrumentality of Russian subjects and by using Russian fortifications in Ciscaucasia. Given that, the tsarevich was also playing his own game in the Caucasus. In 1623, he took to wife a sister of "Kabardian khazi" - an influential ruler Aleguko Shogenukov, whose domain was in so called Kazyeva Kabarda (north-east of Karachai area along the rivers Malka and Baksan) ${ }^{21}$. In doing so, he not only ensured for himself a "toehold" in a strategically important region, but also sealed anti-Russian persuasion of an influential collective of Kabardian nobles.

The events described above can be considered to have predetermined an open conflict of Şahin Geray with Moscow.

Having found himself in Crimea in the spring of 1624, the tsarevich, using his position of qalga (the second person in the khanate) granted by the sultan as a leverage, as well as two thousand of Qizilbash warriors that accompanied him, pursued a policy of his own, quite independent from the khan and extremely aggressive towards Russia. Already on 24 May, having met the Russian ambassadors for the first time, he refused to swear an oath to Mikhail I, robbed the ambassadors and ordered to beat them. In August and September of the same year, Şahin Geray took control over and consequently physically destroyed the Russian embassy to Turkey that landed in Kerch. On 3 September, the very ambassador, I. Begichev, died ${ }^{22}$. Given that tsarevich's order to kill the Turkish ambassadors enraged khan Mekhmed who was faced with it as an accomplished fact,, it is clear that qalga took action without taking possible consequences into account. He described his disaffection towards the potential allies saying that they allegedly killed his father, Saadet Geray ${ }^{23}$.

After the murder of Begichev, for almost three subsequent years Şahin Geray had consistently pressed for break off the relationships between Russia and Crimea. To start with, he constantly victimized representatives of Moscow in Crimea to this end (Y.Dashkov, V.Volkov, O. Prontchischev, R. Boldyrev, D. Skuratov, N. Posnikov) ${ }^{24}$. Secondly, the tsarevich used every opportunity to play the Nogai card by preparing a massive raid on "tsar's borderlands" with Ghazi Ulus's warriors and by attempting, through Ak-murza Baiterekov who fled from the Greater Nogai Horde, to rally nomads of the Volga region

\footnotetext{
18 Meaning neither the Safavids nor the Crimean khanate.

19 Pamiatniki diplomaticheskikh i torgovykh snoshenii... P. 644-650, 529-530.

20 Ibid. P. 529-530.

21 Dzamikhov K. F. "V sluzhbe i oborone...": Kabarda i Rossiiskoe gosudarstvo... P. 96.

22 Novoselskii A. A. Bor'ba Moskovskogo gosudarstva s tatarami... P. 124-126.

23 Ibid. P. 127.

24 Ibid. P. 127-128.
} 
against Russia ${ }^{25}$. Thirdly, in negotiation the qalga put forward unacceptable claims for significant rise in pominki (traditional tribute), "restitution" of Kazan and Astrakhan, as well as liquidation of the Cossacks of Don ${ }^{26}$. However, Şahin Geray did not limit himself to political demarches. In 1626, his troops took part in a raid on the parts of Caucasus whose rulers decided to take an oath of allegiance to the tsar: "they burnt down villages, took captive wives and children, and sent about 100 of them to Crimea to Şahin Geray"27.

Regardless of the fact that from the beginning of 1627 military and political situation of Şahin Geray and the Khan became very dire, the anti-Russian persuasion and actions remained strong, at least until May 1628, when, defying diplomatic immunity, his people took possession of all ambassadors' horses ${ }^{28}$. By that time, the tsarevich' actions had become completely unacceptable to the Russian Tsardom ${ }^{29}$. Nevertheless, prior to the beginning of 1629, Abbas the Great figure was still looming over behind his shoulder; in letters by his name addressed to the tsar, he repeated again and again that "our brother Shangirey khan" supported and wished to reconcile his Eastern European partners ${ }^{30}$. Faced with the double threat of renewed Crimean raids and a possible discord with Iran, Moscow had to wait, until a certain time, confining itself to cutting off diplomatic communication between qalga and the shah, which was effectuated through control zone of voivods of Terek $^{31}$. Soon the patience of the Russian government was rewarded.

At the end of May 1629, having suffered a defeat from the armies of khan Janibek in the battle of Perekop, Şahin Geray fled to the Caucasus. Here, according to the Russian documents, "he lived at his brother-in-law's Aleguka for about half a year"32. In a letter to Mikhail I, the Crimean khan Janibek said that going into hiding at "Kabardian khazi's", the former qalga tried, by way of trading hostages, to make connections with voivods of Astrakhan, Cossacks of Terek and Kabardian nobles ${ }^{33}$. There is also evidence that voivods of Terek "sent warriors to some armed places to retrieve Shen-Girey" ${ }^{44}$. This evidence resonates with Janibek's request to Mikhail I to either "take hostage or destroy" Şahin Geray ${ }^{35}$.

However, it was time for Şahin Geray to reap the rewards of his short-sighted actions in Crimea. Having not had success in political intriguing in the North Caucasus, no later than April $1630^{36}$, he arrived at the court of Shah Safi, attempting, as he did seven years ago, to solicit military and political support of the Safavid Iran. It was his stay in Qizilbash domain that the documents from archival fund 77 of RSAAA pertain to thematically and

${ }^{25}$ A big was did not break out because Turks landed on the peninsula. Despite that, some minor raids took place in the end of summer 1625 (Novoselskii A. A. Bor'ba Moskovskogo gosudarstva s tatarami... P. 116, 127-128).

${ }^{26}$ Novoselskii A. A. Bor'ba Moskovskogo gosudarstva s tatarami... P. 128-129, 132-134.

27 Kabardino-russkie otnoshenia. Vol. 1. Moscow, 1957. P. 110.

28 Novoselskii A. A. Bor'ba Moskovskogo gosudarstva s tatarami... P. 120.

29 Documents of Ambassadorial prikaz bear unambiguous testimony that it was Şahin Geray's conduct in the position of qalga that caused the break in relations (See, for instance: Russko-dagestanskie otnoshenia... P. 109, 113-114).

30 Priezd persidskogo posla Mamet Sali-beka i kupchiny Agi Asana // RSAAA. F. 77. Op. 1. 1629. D. 1. L. 121, 135; Novoselskii A. A. Bor'ba Moskovskogo gosudarstva s tatarami... P. 126.

${ }^{31}$ Priezd persidskogo posla... L. 135.

32 Kabardino-russkie otnoshenia. P. 145

33 Vel'iaminov-Zernov V. V. Materialy dlia istorii Krymskogo khanstva. St. Petersburg, 1864. P. 59.

${ }^{34}$ Kabardino-russkie otnoshenia. P. 145.

35 Vel'yaminov-Zernov V. V. Materialy dlia istorii Krymskogo khanstva. P. 59.

36 The earliest of Shah Safi's letters which deliver message of Şahin Geray's arrival is dated Ramadan 1039 AH [13 April - 11 May 1630]. See below. 
chronologically ("Relations between Russia and Persia") and characterization of which is attempted by the present article.

In the archival unit ${ }^{37}$ that we attempt to analyze there are 21 documents, 19 of which have this or other connections to Şahin Geray ${ }^{38}$. These are a written answer/report of Astrakhan voivods with 9 letters "in Farsi script" attached to it, and their translations. 3 letters (docs. 3, 6, 8) are written in Farsi, 6 (docs. 2, 4, 5, 7, 9, 10) - in the Turkic language. The Turkic language of the Safavid diplomacy is traditionally identified as Azerbaijani. As for the documents in question, we have discovered Azerbaijani phonetic and lexical features only in two of them; these are letters of Shirvan beglerbeg (governor) that can hardly be regarded as "Safavid" in the true sense of the word (docs. 9, 10). Below we have given a full list of the archival documents with a brief characteristics of their content.

Doc. 1. Ll. 1-9. A report of Astrakhan voivods Fyodor Kurakin and Ivan Korobyin. Dated 17 July 1630.

According to the report, the voivods received from the town of Terek 5 letters by Shah Safi I, the former Crimean qalga Shahin Geray, and the Shamkhal of Tarki Ildar (docs. 4-8). Two letters (docs. 2,3) were delivered to Astrakhan by the beglerbeg of Shirvan Qazaq Khan's envoy Nagdaly Sheverdeyev ${ }^{39}$. The envoy had told the voivods the following:

1) Şahin Geray asked Shah Safi to give him soldiers for his Crimean campaign;

2) the Shah sent Şahin Geray to Kazakh Khan in Shemakha and ordered them to raise a 40,000-strong army;

3) it was expected that, returning from Crimea, Şahin Geray would build a fortress at Tatartup ${ }^{40}$.

It should be mentioned that a Safavid governor's envoy can hardly be referred to as a reliable source. The mistrust is aroused particularly by the accounts of the army of 40 thousand people, which is referred to without much of a commentary in most works on the subject that, one way or another, touch upon the would-be raid of Şahin Geray.

Also, at the instruction of Nagdaly, the voivods were asked for military reinforcement for Şahin Geray. Moreover, Russian administrators were to provide for "the roads to Crimea to be clear for them, and that no-one hampers them in any way on the road". The voivods replied to the Qazaq Khan's envoy they were not going to take any action without tsar's order, and sent him his way. Along with that, they decided to start spying on Şahin Geray, and warned the rulers of the Lesser Nogai Horde, Aley Urakov and Bimurza Mamayev, that on no account should they help their long-time ally.

Three pairs of letters form a core of the Turkic and Persian documents (see Table). Each of them includes a firman by Shah Safi and a letter of Şahin Geray. The first pair is addressed to Astrakhan voivods, the second one - to Terek voivods, the third one - to a Kabardian prince Sholokh Cherkasskiy.

${ }^{37}$ Otpiski astrakhanskikh voevod o persidskikh delakh // RSAAA. F. 77. Op. 1. 1630. D.2. 561.

38 Two reports (1l. 44-45 and 46) are dedicated to then current diplomatic problems and do not pertain to the topic researched in the present article. Hereinafter we refer to the documents of that affair according to the list as given below.

39 Another two letters (docs 8 and 9) are not, for some reason, mentioned by the voivodas.

40 Site of Verkhniy Julat situated on the road to the strategically important Dariali gorge. 
Docs. 2-7. Firmans (royal edicts) of Safi I and letters of Şahin Geray

\begin{tabular}{|c|c|c|c|}
\hline Adresser/adressee & Voivodas of Astrakhan & Voivodas of Terek & Sholokh Cherkesskiy \\
\hline Shah Safi & $\begin{array}{l}\text { Doc. } 2 . \\
\text { L. } 10 . \\
\text { Date - Shawwal' } 1039 \mathrm{AH} \\
{[12 \text { May - 10 June } 1630] \text {. }} \\
\text { Translation - l. 11-12 }\end{array}$ & $\begin{array}{l}\text { Doc. } 4 . \\
\text { L. } 17 . \\
\text { Ramadan } 1039 \text { AH } \\
\text { [13 April - } 11 \text { May 1630]. } \\
\text { L. 18-22 }\end{array}$ & $\begin{array}{l}\text { Doc } 5 . \\
\text { L. } 23 . \\
\text { Shavval' } 1039 \text { AH } \\
\text { [12 May - } 10 \text { July } \\
\text { 1630]. } \\
\text { L. } 24-26\end{array}$ \\
\hline Şahin Geray & $\begin{array}{l}\text { Doc. } 3 . \\
\text { L. } 13 . \\
\text { Dateless. } \\
\text { Translation - 11. 13-16 }\end{array}$ & $\begin{array}{l}\text { Doc. } 6 . \\
\text { L. } 27 . \\
\text { Dateless. } \\
\text { L. } 28-32\end{array}$ & $\begin{array}{l}\text { Doc. } 7 . \\
\text { L. } 33 . \\
\text { Dateless. } \\
\text { L. } 34-38\end{array}$ \\
\hline
\end{tabular}

Facts given in Shah Safi's firmans are extremely scarce: Şahin Geray had arrived at the Shah's court and was then sent, accompanied by an army, "to his country" (meaning towards Crimea). Shah's requests are also rather vague: they were to treat Shahin Geray as friendly as possible and to provide him any help he would ask. Thereby, the main goal of the firmans was to legitimize Şahin Geray as an agent of the Shah's will and persuade addressees in that helping Şahin Geray they helped the Shah himself.

The letters of the Crimean tsarevich contain much more information, namely:

1) a list of Safavid rulers who, upon Shah Safi's instruction, were to take part in putting together an army. These were beglerbegs of the vilajets (provinces) of Shirvan, Erivan and Qarabagh, as well as hakims (local military nobility) subordinate to them (docs. 3,6 );

2) an announcement that the raid was to be started soon, when the summer heat had subsided (doc. 3);

3) a request to provide a reinforcement of 1000 Cossacks and 3000 Nogai (doc. 3);

4) a request to organize river crossing sites over Terek and Sunzha to be permitted to use by those who present documents with pertinent seals (docs. 6, 7);

5) a mention that a former voivode of Terek previously murdered («burnt down») an envoy of Şahin Geray (doc. 6).

It is appropriate to give a more detailed characteristic of the addressee of documents 5 and 7, Prince Sholokh Cherkesskiy. He was a head of non-Russian habitants of the town of Terek and played there a significant political role. The activities of the ruler were wellknown in Iran: "Do not give much rein to the princes of Terek"41, the Shah writes in one of his firmans.

Sholokh was related to Şahin Geray ${ }^{42}$ : both of them were espoused to sisters of ruler Aleguko Shogenukov.

In years 1631 and 1634, spokesmen of two Kabardian noble families present humble petitions regarding Sholokh, accusing him of maintaining close contact with Şahin Geray and stating that he was going to participate in the construction of fortifications near

${ }^{41}$ Quoted as per the translation done by translators - tolmachs. The corresponding part of the original is, unfortunately, cut short.

${ }^{42}$ This is conveyed in one of the letters by Şahin Geray himself (doc. 6). See also: Kabardino-russkie otnoshenia... P. 144. 
Sunzha and in "Yeletskoye settlement"43. It is difficult to discern how grounded the accusations were. We would only like to point out that there were more believable accusations brought against Sholokh, those of violations of highland customary law, particularly that of baranta ${ }^{44}$. It is not improbable that the tsarevich's name was mentioned in order for the accusations to bear more significance ${ }^{45}$.

From our point of view, the very fact that we have an opportunity to acquaint ourselves with a firman by Shah Safi and a letter by Şahin Geray addressed to governor Sholokh Cherkesskiy is testimony that the latter was not, at least in the summer of 1630, interested in helping his relative. Otherwise, Sholokh obviously wouldn't have passed these documents on to voivods of Terek.

Şahin Geray, however, seems to have counted on help from Sholokh in earnest: he gave him the role of intermediary between himself and the voivods of Terek. In his letter (doc. 7) he repeats the demand made to the voivods to make a river crossing site over Sunzha and, as a matter of fact, imposes the control over the carrying out of it on Sholokh.

Doc. 8. L. 39. Letter by Shamkhal of Tarki Ildar to voivods of Terek. Not dated. Translated on sheets $40-43$.

The author of the letter is a ruler of Shamkhalate of Tarki, one of the feudal domains of Dagestan that was in vassalage both to Russia and Iran. Ildar was, in point of fact, engaged in the service to Russia in $1622^{46}$; this being said, his contacts with the Persian shah were no secret to the Russian administration. For instance, on 23 March 1623 he was "discovered" by Russian ambassadors V. Korob'yin and A. Kuvshinov during their audience with shah Abbas I. Along with Ildar, none other than Şahin Geray was present at the audience ${ }^{47}$.

Shamkhal of Tarki was, evidently, on friendly terms with Şahin Geray. The people of Ildar were those who accompanied the Crimean tsarevich from Kabarda to Shah Safi. "He (Şahin Geray) confers with Ildar-shevkal", witnesses an envoy of the Kaitag utsmiy in Ambassadorial prikaz. It was Ildar who gave shelter to Şahin Geray in 1632 after the latter, having killed one of the shah's governors, fled from Iran ${ }^{48}$. What's to shamkhal's participation in the events of 1630 , according to M.-S.K. Umakhanov, along with other overlords of Dagestan, he was strongly against both Şahin Geray's raid and building of Iranian fortifications in Dagestan ${ }^{49}$. "The land here is the tsar's domain, not the shah's one", as one of the archival documents quotes Ildar ${ }^{50}$. Nevertheless, the situation does not seem so self-explanatory. E. N. Kusheva states (unfortunately, with no reference to archival documents) that Ildar did, after all, take part in raising an army for Şahin Geray upon Shah Safi's instruction ${ }^{51}$.

${ }^{43}$ Kabardino-russkie otnoshenia... P. 143, 152.

44 Ibid. P. 147.

${ }^{45}$ In this regard, petition by the prince Kelmamet Cherkasskiy presented in August or September of 1634, by the time of which Şahin Geray had spent a year in Turkey already, is especially exemplary.

46 Russko-dagestanskie otnoshenia... P.73.

47 Bushev P. P. Istoriia posol'stv i diplomaticheskikh otnoshenii Russkogo i Iranskogo gosudarstv v 1613-1621 gg. (po russkim arkhivam). Moscow, 1987. P. 142.

${ }^{48}$ Kabardino-russkie otnoshenia... P. 156.

49 Umakhanov M.-S. K. Vzaimootnosheniia feodal'nykh vladenii i osvoboditel'naia bor'ba narodov Dagestana v XVII veke. Makhachkala, 1971. P.171.

${ }^{50}$ Cited by: Umakhanov M.-S. K. Vzaimootnosheniia feodal'nykh vladenii... P. 171.

51 Kusheva E. N. Narody Severnogo Kavkaza... P. 309. 
A letter from Ildar to voivods of Terek (doc. 8) could also be an argument in favour of shamkhal's at least having been in contact with Şahin Geray during that time. There is no mention of the former qalga's name, but the request to "provide for river crossing sites" and "grant passages to those who presents seals" follows Şahin Geray's wordings as per documents 6 and 7 almost word by word ${ }^{52}$.

Docs. 9 and 10. L. 47 and 52. Letters by Shirvan beglerbeg Qazaq Khan with requests to provide help to Şahin Geray, identical content-wise. One of the letters is addressed to voivods of Astrakhan, the other one - to Astrakhan dyaks. On the reverse side of the letters there are lists of presents to voivods and dyaks. Translations are on 11. 48-51 and $53-56$.

In these texts, the Safavid governor neither conveys anything new, nor places any specific demands: being at the service of Shah Safi, Shahin Geray was given a mighty army and sent it to Crimea, in order to restitute his power; it is necessary that any help asked for be provided to Şahin Geray. It is worth emphasizing that the very fact of existence of these letters demonstrates indirectly that Qazaq Khan was one of the main facilitators of Şahin Geray's raid.

All-out diplomatic pressure on Iran amounted to nothing. The Russian government found support for its deterrence of the tsarevich's plans from rulers of Dagestan, including pro-Turkish ones (e.g., Sultan-Magomed of Endirey) ${ }^{53}$. Peace with Crimea and the Ottoman empire in the circumstances of impending conflict with The Polish-Lithuanian Commonwealth was an external priority in politics with Moscow. Shah Safi could not provide actual military support to Şahin Geray ${ }^{54}$. Under these circumstances, as we have mentioned already, the former qalga did the final backflip in his political career by having fled first to the Caucasus and then, via The Lesser Nogai Horde and the Crimean khanate to Istanbul ${ }^{55}$. From there, the tsarevich's route ultimately led to an exile of honor to the island of Rhodes, where he spent the rest of his days.

Consequently, since 1632 or 1633 the Crimean factor had ceased to have a significant influence over Russo-Persian relations. However, in our opinion, the time to establish rapport was lost. Smolensk and Turkish-Persian wars had not only subdued external politics of both the Safavids and the Romanovs, but also threw light upon unpreparedness for coordinated activity, as well as on the presence of considerable problems in which cooperation was technically impossible. In this situation, routine economic and regional safety and security came to the fore of the bilateral relations. Partners never became allies.

52 In doc. 7 Şahin Geray writes directly that not only people with his seal, but also people with the shamkhal's seal, should be let pass.

${ }^{53}$ Kusheva E. N. Narody Severnogo Kavkaza... P. 309-310, 313-315.

54 The Cambridge History of Iran... P. 280-284.

${ }^{55}$ Kusheva E. N. Narody Severnogo Kavkaza... P. 314. 
Annex

Firman of Shah Safi to voivods of Terek I. A. Dashkov and

B. G. Priklonskiy ${ }^{56}$

(1) [فرمان همايون صادر] اولاى كيم امارت و حكومت مآبين عمدتى الامراء و الحكام المسيحيه ترى

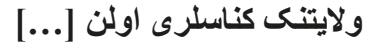

(2) [... عنايت] بيغايت شاهانه و عاطفت بينهايت يادشاهاتم بيرله معزز و ممتاز و مفتخر و سرافراز

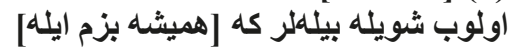

(3) [...] اوروس بادشاهلرى مابينتده طريقه محبث و دوستلق مرعى ونهايث اتحاد و يكانلق [مسلوى اولمش?]

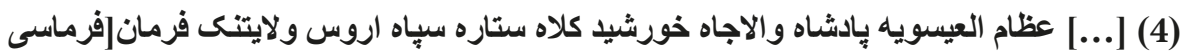

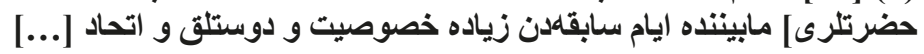

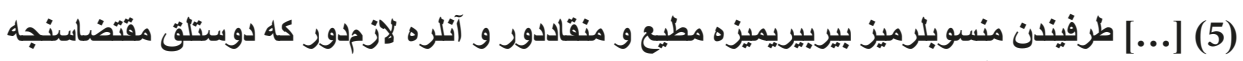
نيجوك كيم بادشاه عليجاه

(6) [...] و متابعت ايدرلر بيزوم فرمان همايونوزه دخى متابعت ايدهلر جون بو ايامده سلطنت و شوكت بيناه نصفت و معدلث دستكاه

(7) [عمدت] السلطه و الجلاله قرم و تاتتار ولايتنى خان و خانز ادهسى اولن شـاهن كراى خان

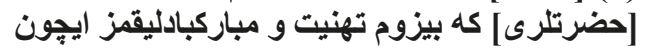

(8) [...] مرخص ايدوب اوز ديارنه كوندرلاى و خاطر عاطر همايونمز اونتى حصول مطالب و وصول مدعاسنـه

(9) [...] كركدر كيم اول صوبه وصول بولاقده مومى اليه ايلن محبت و دوستثلى شيوهسينى مرعى و مسلوك طوتوب

(10) [...] و يولاشلث اللرندن كلورايسه ظهوره كتوروب لثكر قوشمكدن و كومك ايتمكدن و اولكه

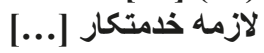

(11) [.... كd هر آينه

(12) [...] بائشاه والاجاه خورشيد كلاه حضرتلرى مابينتده موجب ازدياد مواد محبث و دوستثلى اولور

(13) [ و من كل] الوجوه عنايت بيغايت يادشاه همايونمزه اميدوار اولوب هر مطلب و مدعالرى وار ايسه عرضهداشت قيلهلر كه

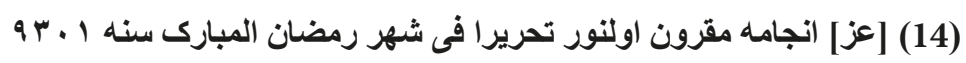

Перевод с шаховы с грамоты, какову прислали с Терка воеводы княз Иван Дашковъ да Богдан Приклонской ${ }^{57} 138$ году июля въ 17 день $^{58}$, а к нимъ прислалъ кизылбашской шах Суфиі:

${ }^{56}$ Otpiski astrakhanskikh voevod o persidskikh delakh... L. 17-22. Parts of the Turki text that were lost we marked by [...].

57 The translation following the firman here allows us to see how close to the original text the translated version is.

58 The letter $\mathrm{Z}$ with the symbol $\neq$ is omitted, hence the date indicated in the text is 17 July 7138 anno mundi, or 17 July 1630. 
«Указ шаховъ то есть: от дъдовъ и отцовъ князья бывали великии исусовы въры терские отчины болшому князю и меншому князю от шаха милостивое жалование. На шахово жалование надежным бы бысть. Это ведайте вы, у наших дъдов и штцов с рускими государи меж ими дружба и соединенье бывало и ныне с нашим государем с шахом исусовы въры, великиі государь и венецъ ево на главъ аки солнцъ сияет и многшлюдныи что звебздъ на небе рускиские области и над государи государь величествшмъ своимъ, и меж ими и исстари, и вперед свыше дружба и любовь и соединенье есть. Здъся и у васъ владбтели, и шни меж себя в дружбе и въ братстве. И ныне б вамъ, князьямъ, что своево великого государя указу слушаете, ещо б и нашево шаха указу слушати. И ныне эвто время от дъдов и от отцов царь бывал многолюдныи крымскихъ татар вотчины царскои сын Шангирьи царь к царскому величеству, к намъ, поздравляти ко вратом нашимъ приъхал из своеи земли и ныне, пожаловав, в свою землю штпустили мы, государь, от своего живота, любя. Похочет хто ни есть, і в ть отчины прибдет, і с ним бы царем дружбу и любовь и соединенье, и какая ни есть служба будет мочно руками учинить, ино б зделал: рати 6 и пособство сколко будет надобно дати - ничъм бы не оскорбити. Так бы здълати царскому б величеству от васъ любо было для того, чтw у нас с великимъ государемъ с пресвътлымъ венцом съ его величеством меж нами дружба и соединенье і своіство есть. Еще какое ни есть дъло будет милостивое б наше жалованье к себъ видели, что ни есть дъло будет, милостивое 6 наше жалованье Һ̌ебъ видели. Что ни есть понадобитца - с челобитьемъ пришлите, пожаловав, пришлемъ.

Писан этот указ в ромазане месяцъ 1039 году, по руски в мае месяцъ».

\section{Translation from Turki ${ }^{59}$}

[An august decree] was issued. Princes of Terek, paragons of bravery, strongholds of ruling and pillars of Christian rulers, are dignified, distinguished, endowed and blessed with illimitable shah's [kindness] and endless sovereign's benevolence.

Let it be known to them that [between us] and $<\ldots .>$ Russian sovereigns there has long been a path of love blazed and friendship and the highest degree of unity and solidarity [established]. And now the friendship, unity and mutual affinity between the August Substitute ${ }^{60}$ and [the Pillar of] Christian sovereigns, the high-ranking, crown-bearing [potentate] of the Russian Tsardom, whose army is as numerous as the stars in the sky, are as strong as never before; and subordinates of one sovereign obey and submit to another. It is required that they, by way of friendship, obey to our August firman, as they do obey [orders] of the High Sovereign.

Recently Crimean and Tatar khan and khanzade ${ }^{61}$ Şahin Geray-khan, a shelter of mightiness and majesty, a stronghold of nobility and justice, bearer of power and magnificence, [arrived at our court], in order to greet and congratulate us ${ }^{62}$, and [soon] was sent [by us] to his country. Our high-pitched ambition [is to help] him to obtain his goals and to realize his aims.

\footnotetext{
59 Translated by T. A. Slesarev.

60 The Safavid shahs were Shiites and regarded as substitutes of the first Shiite Imam Ali.

${ }^{61}$ I. e., khan's son - successor - is the title that the tolmachs translated as tsarevich.

${ }^{62}$ Conceivably, this refers to congratulations on accession to the throne.
} 
When he arrives in that country, it is required that they follow the accustomed path of friendship and love in what concerns him $\langle\ldots\rangle$ and provide him all possible assistance. Military reinforcement and help and anything that needs to be helped $\langle\ldots\rangle$ let it be made so that the above-mentioned khan is totally satisfied and content, and let it become another cause for strengthening of our love and friendship with the crown-bearing Sovereign.

Let them be constantly assured of our endless August benevolence and, should they have any requests or pleases, let them address us with their petitions - and such shall be accomplished in the best way possible.

Written in the sacred month of Ramadan of year 1039 [13 April - 11 May 1630].

\section{Commentary}

This firman is a kind of travelling paper, which shah's envoys and merchants presented to voivods when going through their city ${ }^{63}$. The formulary of such kind of documents was characterized by the following:

1) a formula for expression of shah's benevolence, an inherent part of the initial protocol ( $1^{\text {st }}$ paragraph), following the inscription (naming the addressee);

2) extensive preamble ( $2^{\text {nd }}$ paragraph) preceding the narrative part of the text in the form of profession of "love, friendship and unity" between the shah and the tsar. The aim of these professions was to suggest why the addressee, in the first place, had to follow orders from a head of another country. A specific feature of this document is that the need to "obey to the august firman" is expressed explicitly in it.

Docs. 2 (firman to voivods of Astrakhan) and 5 (firman to Prince Sholokh), while being, on the whole, very similar to the firman herein, also presents a number of telling differences. In doc. 2 , the shah reprehends the voivods for showing "extreme disdain" to his benevolence, and he does not write a word about the "love and friendship" between him and the tsar. In document 5 , there is no mention of the friendship between the monarchs either. This indicates that the shah did not perceive Sholokh as a subject of the Russian tsar.

Travelling letters addressed to Russian voivods can be included into a broader category of documents, that of Safavid shahs' firmans addressed directly to subjects of other monarchs. As it was pointed out by L. Fekete, such firmans were quite a common diplomatic practice of the Safavids ${ }^{64}$.

\section{References}

Babulin I. B. Russo-Persian Military Conflict of 1651-1653. Reitar, 2006, no. 31 (7), pp. 6-33. (In Russian) Bazilenko I. V. Essays on the History of Russian-Iranian Relations (end of $16^{\text {th }}-$ early $20^{\text {th }}$ c.). St. Petersburg, Argus Publ., 2017, 431 p. (In Russian)

Belokurov S. A. A Document on Sending the Chiton of the Lord to Mikhail Fyodorovich by Shah Abbas I in 1625. Moscow, Typ. of E. Lissner and Iu. Roman Publ. [2], 48 p. (In Russian)

${ }^{63}$ One of the travelling letters was previously made public: Shorokhov V.A., Slesarev T.A. Firman persidskogo shakha Abbasa I astrakhanskomu voevode iz fondov RGADA // Klio. 2019. No. 4 (148). P.2833.

${ }^{64}$ Fekete L. Einführung in die persische Paläographie. Budapest, 1977. S. 52. 
Bushev P. P. The History of Embassies and Diplomatic Relations between Russian and Iranian States in 16131621 (following Russian archives). Moscow, Nauka Publ., 1987, 280 p. (In Russian)

Bushev P.P. The Embassy of V.G. Korob'in and A. Kuvshinov to Iran in 1621-1624. Iran. Ekonomika. Istoriia. Istoriografiia. Literatura. Ed. by N. A. Kuznetsova. Moscow, Nauka Publ., 1976, pp. 124-155. (In Russian)

Dzamikhov K. F. "Going about the Duty and Defence": Kabardia and the Russian State: the Era of Political Military Cooperation (1550 - early 1770 ths $)$. Nalchik, RAS KBSC Institute of Humanities Press, 2017, 353 p. (In Russian)

Dzarasov A. A., Riabtsev A.L. The Conditions of Russian Maritime Commerce in the Caspian in $17^{\text {th }}$ century. Vestnik of Khetagurov North Ossetian State University. Social Sciences, 2013, no. 1, pp.20-24. (In Russian)

Fekete L. Einführung in die persische Paläographie [An Introduction to Persian Palaeography]. Budapest, Akademiai Kiado, 1977, 594 S., [121] Bl. Faks.

Filatova T. "And it's Forbidden to visit Shah in His Clothes": Russian Officials at the Court of Abbas the Great. Rodina, 2009, no. 12, pp. 158-161. (In Russian)

Koraev T.K. Muscovite Russia and Safavid Iran in the Caspian Region during $16^{\text {th }}-17^{\text {th }}$ cc.: Neighboring, Cooperating, Coexisting. Istoricheskii vestnik, 2015, vol. XI (158): Rossiia i islamskii mir, pp. 154-199. (In Russian)

Kostikov S.E., Yastrebova O.M. Petitions of the Iranian Kupchina (Merchant) Khwaja Rahmat to Tsar Mikhail Fiodorovich (1613-1645) from the Russian State Archives of Ancient Acts. Pismennye pamiatniki Vostoka, 2019, vol. 16, no. 2 (37), pp. 122-145. (In Russian)

Kukanova N. G. Essays on the History of Russo-Persian Trade Relations in $17^{\text {th }}-$ first half of $19^{\text {th }} \mathrm{c}$. (following the records from Russian archives). Saransk, Mordovian State Publ. House, 1977, 286 p. (In Russian)

Kusheva E.N. The Proceedings of the Scholars Session on the History of the Peoples of Dagestan: RussoDagestan Relations in $16^{\text {th }}-17^{\text {th }} \mathrm{cc}$. Makhachkala, 1954, 27 p. (In Russian)

Kusheva E. N. The Peoples of the North Caucasus and Their Relations with Russia (second half of $15^{\text {th }}-$ $1830^{\text {ths }}$ ). Moscow, USSR Academy of Sciences Press, 1963, 368 p. (In Russian)

Meskhia Sh. A., Tsintsadze Ia.Z. From the History of Russian-Georgian interrelation. Tbilisi, Zaria Vostoka Publ., 1958, 149 p. (In Russian)

Murtazaev A. O. Kajtag in $8^{\text {th }} I-$ first half of $19^{\text {th }}$ c. (a Study in Its Political History and Role in Sociopolitical Structures of the North-West Caucasus). Makhachkala, RAS DSC History, Archaeology and Ethnography Institute Press, 2015, 489 p. (In Russian)

Novoselskii A. A. A Struggle of the Muscovite State against Tatars in the first half of the $17^{\text {th }}$ century. Moscow; St. Petersburg, USSR Academy of Sciences Press, 1948, 448 p. (In Russian)

Novosel'tsev A.P. Russo-Persian Relations in the first half of the $17^{\text {th }}$ c. Mezhdunarodnye sviazi Rossii $v$ XVII-XVIII vv. (ekonomika, politika i kul'tura). Moscow, Nauka Publ., 1966, pp. 103-121. (In Russian)

Shorokhov V. A., Slesarev T.A. Firman of Shah Abbas I of Persia to the Voivode of Astrakhan from the RGADA funds. Klio, 2019, no. 4 (148), pp. 28-33. (In Russian)

Shorokhov V., Yastrebova O., Rezvan M., Pischurnikova E., Andreev A. Shāh Safī i Safawid's "missing manuscript" addressed to Mikhail Fyodorovich Romanov. Manuscripta Orientalia, December 2018, vol. 24, no. 2, pp. 62-67.

Trepavlov V.V. The Lesser Nogai Horde. Essay on History. Tiurkologicheskii sbornik. 2003-2004: Tiurkskie narody v drevnosti i srednevekov'e. Ed. by S.G. Kliashtornyi, Moscow, Vostochnaia literatura Publ., 2005, pp. 273-311. (In Russian)

Umakhanov M.-S. K. The Relations between the Feudal Possessions and the Fighting for Freedom of the Peoples of Dagestan in $17^{\text {th }}$ century. Makhachkala, 1971, 251 p. (In Russian)

Zevakin E. S. Azerbaijan in the early $17^{\text {th }}$ century. Baku, Azerbaijan Studies Society Press, 1929, 32 p. (In Russian)

Статья поступила в редакцию 12 декабря 2019 г. Рекомендована в печать 12 марта 2020 г.

Received: December 12, 2019

Accepted: March 12, 2020 